\title{
The disappearing Mammy Water myth and the crisis of values in Oguta, South Eastern Nigeria
}

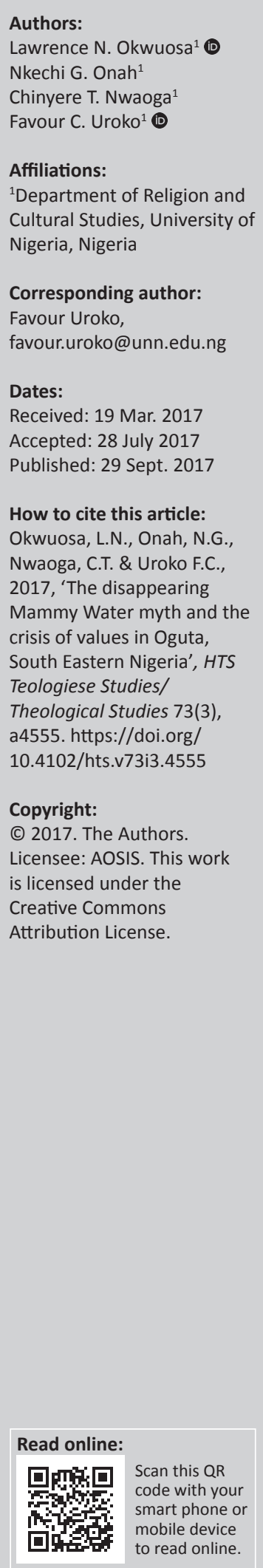

Igbo value system is in crisis with an increase in crime rate, kidnapping, stealing, sexual immorality and divorce. Though several reasons have been given for this malaise, the influence of myths on value system has not been explored. To do this, we chose Oguta town in SouthEastern Nigeria, known for its belief and worship of Mammy Water. The intent is to verify if the disappearing myth has any adverse socio-cultural implications on the town. As the disappearing myth deals principally with the people's life, the research methodology used historical as well as the descriptive phenomenological methods. These methods explain the phenomenon as it appeared in Oguta objectively from the historical point of view. One-on-one interviews and focus group discussion with the natives were carried out, thus making oral literature an important element of this research. It comprises three groups: the first group has the age bracket of 70 years and above; the second group has 40-69 years as age bracket and the last group has 20-39 years as age bracket. Efforts were made to distinguish meaningful facts from fictitious or emotional ideas expressed by the participants. Information was also gathered from published works. The research was able to identify the myth's disappearance as a major contributing factor to the town's crisis of values.

\section{Introduction}

The era of myths has been variously described as the pre-logical time in human's history when people believed in gods and goddesses, whose existence and powers were merely the figments of human's imagination. Popular understanding views this to mean that myths are untrue and without any historical backing (Anyacho 2005:12). This kind of submission makes so little of the human spirit, which conceives truth in various ways, especially from its functional aspect. According to Armstrong (2009):

myths may have told stories about gods, but they were really focused on the more elusive, puzzling, and tragic aspects of the human predicament that lay outside the remit of logos. Myth has been called a primitive form of psychology. (p. xi)

As psychology, a myth was aimed at forming people's mind. Before African cultures succumbed to the dominant external cultures and, now globalism, myths were one of the most reliable sources of education, communication, character moulding, installation of peace and unity in the community. Okpewho (1983) narrates that the real basis of myth is not thought but feeling, in it the sensible present is so great that everything else dwindles before it. Hence, it formed part of the unwritten codes of human behaviour written in people's hearts and transmitted from one generation to another unbroken. As this was done in the spirit of communal duty, people's sense of origin and future were formed and sustained. They were drawn into communion with their forebears, who represented their past and in a way their future. Then, for Africans, there was no existential dichotomy between the past and present generations with myths. The different ages were nourished by the same knowledge source. They were expected to act and behave alike with regards to the culture and tradition of the land. This is because according to Mbiti in myths lies a rich wealth of ideas, beliefs, values, literary expressions and the exercise of human imagination (Anyacho 2005:13).

Taking these things into consideration, it is obvious that if Africa's cultures have abandoned the myths that nourished and sustained them like their forbearers that they would not act and live like them anymore. They are bound to fall to the basic principle of change, which is the only permanent thing in life. But what are the possible consequences of this change? What could be the nature of this change? Would it allow for the essential continuity between the past and the present that has sustained African societies in terms of the African identity and the rich African cultural values? 
The choice of Mammy Water myth and Oguta people is critical in the sense that though the myth is well known among the Igbo ethnic group of Nigeria, her abode is Oguta Lake. It is a myth, which in the past greatly influenced the people's social, ethical and religious life. This was extensively documented by Flora Nwapa, Nigeria's First Lady of Letters and a native in her masterpiece, Efuru written in 1966 (Nwapa 1966). In her over 20 years of study of Mammy Water in Igbo Culture, Jell-Bahlsen's subject matter was the Mammy Water (Ogbuide) of Oguta Lake (Jell-Bahlsen 2014). Even though these studies tried to bring into limelight the myth's importance in the people's lives, no real study has examined the possible effects of its disappearance in the town. In view of this, there is the need to investigate the social, ethical and religious life of the people without the goddess.

The course of this research would include the following: studying the general understanding of the myth in Oguta, identifying Igbo values that are inherent in the myth, fathoming factors responsible for the disappearing of the myth, the resultant crisis of values, the way forward and conclusion.

\section{The Mammy Water myth in Oguta cosmology}

Oguta is an ancient lake town in Igbo land. Because of its water link with the famous River Niger, it became a big economic centre for palm products, yams and fish (Agorua 2015). The people's belief and worship of Mammy Water is as old as the history of the people's sojourn in the land. According to oral tradition, it was the goddess of the lake that chose the people. In the early 19th century when the town was migrating from the old Benin Empire, a certain fisher man Eneke Okitutu, strayed in his fishing expedition and found himself in the lake. He was moved by its glamorous beauty and fish that he went home and mobilized his people. They succeeded to ransack Awa people who were the original inhabitants of the town (Ofili 1998).

The goddess of the lake Mammy Water is known to the natives as Ogbuide or Uhamiri. She is described as a black beautiful woman with the tail of a fish and long black hairs flowing down her shoulders, which she combs with a golden comb. Around her neck are pythons. She is very wealthy and used different kinds of fish as firewood (Nwapa 1966:146). Unlike the other deities in the town, which are worshipped by specific families and villages, she is worshipped by the whole town. She is the reference point in the people's daily life. In the past, as soon as a child was born, it is fed with water from the lake and the mother before resuming her social life put her legs in the lake (Nwapa 1966:33). This rite is performed when somebody dies. The dead person is washed with water from the lake water before burial and the partner at the end of the prescribed mourning period takes his or her bath in the lake. The lake is believed to be the entrance and exit points of every human life in the town. In fact, the natives are called Ndi Mmiri [people of the lake]. The woman of the lake, as the goddess is also called, is worshipped as the goddess of fertility and productivity. She is believed to give barren women children after they agreed to serve her (Jell-Bahlsen 2014:29).

With the bond established at birth, all the natives are believed to be connected to the goddess. This notwithstanding, she has her strict worshippers or ministers, whom she chooses and empowers. Among them are Eze Ugo [the goddess' priest], Eze Nwanyi [the goddess' priestess], Dibia Mmiri [water herbalists], Ogbuides [the goddess' reincarnates], Dada [chosen ones], Nwa Mammy Water [a special devotee], ndi egwu amara [lake dancers], etc. These special worshippers besides having the lake water as shrines in their homes are to keep her taboos. Some of the taboos as recorded by Nwapa (1966) are:

Orie day is her great day. You are not to fish on this day ... you should persuade others not to fish. You are not to eat yams on this day. (On this day too) You are not to sleep with your husband (wife). You have to boil, roast or fry plantains on Orie day. Uhamiri likes plantains so much. You can even pound it if you like. When you go to bed, you must be in white on Orie nights. You can sacrifice a white fowl to Uhamiri on this day. When you feel particularly happy, or grateful, you should sacrifice a white sheep to her. Above all you will keep yourself holy. When you do all these, then you will see for yourself what the woman of the lake would do for you. (p. 151)

Other ordinances include forbidding of the killing or eating of aquatic tortoise, crocodile, and python, that are her favourites animals. Menstruating women, mourning widows and widowers and people under oath are also forbidding from bathing in the lake. Likewise, teenagers are not allowed to bath with their clothes in the lake (I. Ezeugo, pers commun, 12 March 2015).

Besides giving children to women, the woman of the lake is known to make people especially women wealthy. She protects the town from invaders, diseases, and misfortunes. The lake naturally serves as a protective shield for the people from invaders. It is believed among the natives that people with dangerous charms, murderers, adulterers, rapists, thieves cannot cross the lake without any negative consequence on them. According to oral tradition, the goddess protected the town during the Nigeria-Biafra war in 1968 by capsizing all the enemy's gunboats that ventured into the lake to attack the people (I. Ezeugo, pers commun, 12 March 2015).

\section{Fundamental Igbo values in the Mammy Water myth}

The myth of Mammy Water is adduced as a religious belief. Like every other religious belief in Igbo culture, it is a gift from Chukwu [God] rich in traditional values. Some of the values easily discernible from the myth are given in the following.

\section{Respect for life and human dignity}

Life, among the Igbo people, is considered the highest gift from the Supreme God, Chukwu. Every other gift from God is founded on life and among all the things that have life 
human being is the most precious thus buttressing the name Mmadu, which means the beauty of life. Human life is very precious that the murder of a relation, suicide, euthanasia, and abortion are considered abominations and desecration of the land.

To portray the inestimable value of life among the Igbo people, we have Igbo names like Ndubuisi [life is supreme],

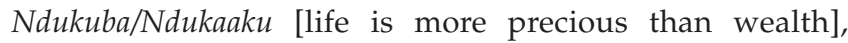
$\mathrm{Ndudi}$ [with life there is hope], Ndubueze [life is king], Nduma [life knows all], Ndulaka [life decides all], etc. In the same vein, to show how close human life is related to God, we have Igbo names like Chibundu [God is life], Chinwendu [God owns life], Chilendu [God is life's provider], Chikwendu [God wills life], etc.

Because of the value attached to life, the people perpetuate it via procreation and the belief in reincarnation. These are two basic beliefs that the Mammy Water myth propagates. The goddess, as we have pointed out already, is known for giving children to barren women. Her ordinances are pro-life and deter the natives from doing anything that might endanger other people's lives. Her disdain for death is unequalled in the sense that anything dead does not pass through the lake without appeasement. In this culture, euthanasia, abortion, capital punishment is unheard of. They are intolerable and merit immediate punishment from the goddess. On the contrary, Christianity, though it does not support the above vices, tends to be merciful to the offenders (Mt 5:7).

\section{Gender sensitivity}

Igbo culture is adduced to be patriarchal by nature and tends to limit the operational sphere of the womenfolk (Achufusi 1994:159). On the contrary, this is not the case in Oguta. Even though in some Igbo communities, some women are priestesses, the office is majorly dominated by men. In the mammy water cult in Oguta, it is purely all women's affairs at the top cadre. The Eze Ugo who is a male priest is an exceptional case. In fact, in the history of the town, only one man has held the position and he was the father of the Eze Nwanyi, Ifunaya Ezeugo (I. Ezeugo, pers commun, 15 March 2015). Mammy Water's ministers and strict members are mostly women and they are abundantly blessed. This is what the native doctor explained to Efuru, a new recruit of the goddess, concerning her calling in Nwapa (1966):

You are a great woman ... It is a great honour. She is going to protect you and shower riches on you. But you must keep her laws. Look round this town, nearly all the storey buildings you find are built by women who one time or another have been worshippers of Uhamiri ... Uhamiri is a great woman. She is our goddess and above all she is very kind to women. (p. 153)

Invariably, the myth recognises and promotes women in the society. Mammy Water is the symbol and patron of women's wealth (Jell-Bahlsen 2014:145). In fact, Oguta women, who are more successful traders than their husbands, are believed to have received their wealth from Mammy Water. Because of this, they are socially and economically independent and mobile. Even today, Oguta women may marry other women for her husband or marry wives for her son. Following Mammy Water's requirements of sexual abstinence for 2 years after a child's birth, an Oguta woman would at most bear two children in 6 years. This practice has been adjudged beneficial to women and puts lesser burden on the family (Jell-Bahlsen 2014:143, 250).

Recognising the physical weakness and vulnerability of women, the goddess never failed to protect Oguta women at their moments of needs and against exploitations. A good example is the story of an Oguta girl whose pot of soup was tampered with by another patient in a hospital at Onitsha. After crying, the girl prepared another pot of soup with fresh fish from the lake. As usual, the thief went again for the soup but this time in the attempt to take fish from the pot, her hand hooked to the fish's head in the pot of soup. She cried out in great pains and was thus caught red-handed. The Oguta girl on seeing what has happened started singing and praising the goddess in these words: 'The woman of our lake has fought for one of her daughters today' (Nwapa 1966:130). The general belief of the people is that the woman of the lake protects not just the women and children but everybody. It could then be said that the myth is the champion of gender equality against the Christian impression that women are merely a rib of man (Gen 2:22) and his helper (Gen 2:18).

\section{Promotion of respectable togetherness}

In Africa, the community is the supreme custodian and strength of all. The individual person belongs to the community who forms and guarantees each individual's identity. In view of this, the individual person believes what others in the community believe (Mbiti 1969:67). This is the case in Igbo land, where the individual is regulated and measured according to the acceptable norms of the society. A person's importance and dignity are measured according to his or her integration into a given community and active participation in its beliefs and traditions.

In Oguta, the rallying point for the community in terms of identity, beliefs and occupation is the lake and its goddess. They derive their identity from the lake as Ndi Mmiri. They also derive their sustenance as farmers, fishermen and traders and social norms for peaceful coexistence from the ordinances of the lake goddess. For example, despite the fact that the lake is the people's centre of interaction, there are basic norms to uphold in order to curb immoralities in the town. For example, men and women, even when they are married, are prohibited from swimming together in the lake (Nwapa 1966:137), going out together at night (Nwapa 1966:118) and kissing in public (Nwapa 1966:122). Furthermore, anyone who killed his kinsperson atones for it till death (Nwapa 1966:151), anyone who stole was sold into slavery (Nwapa 1966:176) and anyone who took a false oath and died of it was thrown into the evil forest (Nwapa 1966:183). In this way, a healthy togetherness was built that guaranteed everyone a safe space to operate. Women, men, and children have their different but complementary roles to play in the 
house, farm and society. According to Achebe (1958), Christianity has touched the things that have united the traditional people making the centre not to hold anymore for them. Christianity in Igbo land is multifaceted. It has different denominations whose doctrines contradict themselves and put their members at loggerheads.

\section{The Sense of the sacred}

In Igbo traditional culture, profanity does not exist. Everything is sacred because everything belongs to the gods or inhabited by the gods. The Igbo existential experience is one that involves fully the participation of the divinities in various ways. Hence, Igbo life is roundly religious and sacred. It is the same value that the myth of Mammy Water creates in the life of Oguta people. The woman of the lake is their daily companion. She is revered at all times, at birth when people are happy and at death when they are sorrowing and invoking her help. Accused persons swear in her name to prove their innocence while the guilty dread mentioning it. The belief is that wherever her shrine is enthroned the place and the people involved must be pure and honest. Hence her ministers, Eze Ugo (the priest), Eze Nwanyi (the priestess) and Dibia Mmiri (water herbalists) in order to be effective must avoid evil. They cannot divinise anything if they commit evil or work effectively for a person who is evil. Evil blinds them from seeing the gods (Nwapa 1966:152).

With the myth, the people are conscious of their relationship with the gods and their dead ancestors, especially with regards to the observance of the numerous rites and ordinances prescribed by the lake goddess. Christian understanding of the imperative 'subdue and lord over the earth' (Gen 1:28) creates a dichotomy among created realities. Christians kill at will local totems to exhibit this dominion against the tradition of the local people (Achebe 1958:112).

\section{Factors responsible for the disappearing Mammy Water myth}

Western civilisation in its varied forms has been blamed for the cultural change in Africa. According to Omirima, the village gossiper in Nwapa's Efuru, said that: 'The world is changing. It is now the world of the white people. We and our grandfathers don't seem to count these days. We are old' (1966:194-195). Ajanupu another prominent character in the celebrated novel reiterated this: 'Only school children are ignorant of our customs and traditions' (Nwapa 1966:212). The fact remains that culture clashes and changes are inevitable phenomena in the world that is continuously turning into a global village. In this situation, one culture freely and gradually assimilates qualities from another or one culture is enforced on another based on superiority complex or supremacy theory. In the later case, inestimable values are lost with the negation of people's unique life experiences and beliefs.

In the case of the Oguta people, formal Western education and Christian religion were craftily introduced to displace the people's cultural practices and traditions. This religious colonisation and foreign incursion affected greatly the Mammy Water myth.

Formal Western Education: Ukeje (1978:2) defined education as a process by which people are acclimatised to the culture into which they are born in order that they may advance. In the simplest language, it is the process by which people are prepared to live effectively and efficiently in their environment. Using this as the benchmark for our study, we can say that education is a process of self-discovery, which includes the mastering of oneself and environment. Through education, one becomes not only useful to oneself alone but also relevant to the entire community of provenance. Resultantly, education enhances community values.

Prior to the advancement of the colonial masters in Nigeria and the arrival of Christian missionaries, each ethnic group had its own traditional form of education based on its own culture and tradition. The curriculum that is informal comprises developing the child's physical skill, character, intellectual skills and sense of belonging to the community as well as inculcating respect for elders and instituted authority and giving specific vocational training and the understanding and appreciation of the community's cultural heritage (Imam 2012:182). The family system played an important role in this form of education. Grandparents most of the times had the duty to look after their grandchildren and in this way inculcate to them the customs and tradition of the people. Obviously, the wisdom, ageless cultural values and traditions of forbears were effectively passed to the younger generation.

With formal Western education, the priority shifted from local content preservation and enhancement to that of sustaining the interest of the colonial masters, which was mostly commercial. Enwo-Irem (2013:165) noted that the motive behind the introduction of formal education by the colonialists was not really aimed at enhancing the development of their colony Nigeria. The colonial agents had a series of problems in administrating the people and in the exploitation of natural resources in the land. They had the problem of acceptance of the colonial agents in some parts of the country and that of language barrier in areas where the local people appeared to have accepted the colonial agents. So they decided to use education to tackle some of the problems and not empower the people to be self-reliant, confident and proud Africans, who would uplift their culture and tradition.

Because the interest was more on educating vital personnel who would service the chains of production in the colonial administration and serve as internal eyes and ears, a kind of saboteurs, for commercial and economic imperialists, the scope and standard of education received by the natives were limited. They were trained merely as gardeners, carpenters, masons, tailors, clerks, interpreters, catechists and local school masters (Nwankiti 1996:36). These 'chosen' few were made to feel privileged and important over others. Armed with the power of a foreign language that others did not understand, a well-paid job and the connection of the 
masters, they became little 'lords' over their own people, in imitation of their arrogant and rapacious colonists. They started treating their people, especially the village heads and chiefs, with scorn and even challenged their authority. To undermine the local powers and demonstrate their superiority over them, the learned natives started undermining the cultures and traditions of the people without any reprimand from their colonial masters. Consequently, the individual interest was enthroned over the communal interest. The traditions and customs were eroded. Seeing this new-found liberty and the largess that goes with it, so many people, especially those who felt disadvantaged and deprived in the society, embraced Western education as a way of emancipating themselves. A new culture was enthroned displacing the people's culture and tradition.

Consequently, according to Jell-Bahlsen (2014:1-2), local myths were seen as old garbage, fetish, pagan and meaningless ramblings of primitive minds that have no place in the modern world of science and technology. They were seen as imageries without the capacity whatsoever to salvage man or help him discover the true meaning of life. Hence, colonial research was slow to accept the notion of an African water goddess. The conquerors of territories were more interested in the earth than in water they could not control and whose importance they would not fathom. Yet, African villagers have long known about the importance of water and its goddess to their existence, survival, and well-being. Though women bring children and life into this world, there is no life without water and the goddess that guarantees it.

The colonialists' reluctance to learn from the natives or incorporate their culture into the new emerging culture is an old rhyme recited everywhere in the black African continent. It shows the culture of obliteration, which the Mammy Water myth was subdued. By discrediting the myths as credible educational sources, the natives were denied not only a didactic means akin to their cultural nature but also a unifying link with their ancestors. By discrediting the myths, the people's worldview and values were debased.

Christian Religion: Christianity in Nigeria, as anywhere else in Africa, was motivated by the will to evangelise and extricate the people from the devil's jaws and eternal hell fire. With this objective, Christian missionaries in Africa worked tirelessly to substitute African Traditional Religion (ATR) with Christianity. There was no design for religious dialogue, enculturation or acculturation. To justify their mission, according to Ugwu and Ugwueye (2004) ATR was contemptuously described as native, pagan, heathen, juju, fetish, animism, idolatry, primitive and polytheism. It was associated with anything denigrate like witchcraft, ghosts, hobgoblins, charms, superstitions, evil omens, magic, etc.

This dialectical approach employed by the missionaries which negated any form of dialogue with the people in terms of ethos, socio and religious values, in their proclamation of the gospel, put the gospel and the recipient culture at loggerhead. There was complete derision, condemnation and destruction of Africa Tradition Religion's native rites, arts and artefacts by overzealous churchgoers. Shrines and native places of worship were burnt and sacred observances violated. Sacred totems were killed (Achebe 1958:112). Mammy Water was not spared. Awfully, the act of demonising the other, which happens to be the Christian tactic, was employed on the myth and it was roundly condemned. She was called a mermaid and queen of the coast. Jell-Bahlsen (2014:237) revealed that diverse water gods and goddesses were all lumped together as 'mammy water' and branded as 'aquatic evil spirits'. The term Mammy Water was used as a simplified synonym for all water deities and, moreover, placed on the same level or associated with physical properties such as barrenness, accidents, untimely death, etc.

The resistance by the natives was not enough to forestall the incursion and destruction of their culture by the combined efforts of the missionaries and their nationalists, the colonial masters (Achebe 1958:114). Native culture and tradition yielded to the demands of the gospel involuntarily and cosmetically. The result is that today many Africans are inwardly more Traditionalists than Christians. In their different Christian denominations, they have imported certain aspects of ATR like songs, titles, clapping of hands and superstitions. Some of these Christian believers in their moments of crisis seek help more from the native religion than from Christianity.

\section{The crisis of values in Oguta}

With the emergence of the new religion and the new civilisation necessitated by Western education in Oguta, the people noticed changes in their way of life and interaction with one another. This change was well illustrated in Nwapa (1966):

What are we going to do about thieves in this town? The world is bad. In my youth, there was no stealing. If you stole you were sold as a slave. If your property was stolen, you simply went to one of the idols and prayed him to visit the thief. Before two or three days, you recovered your property. But these Church-goers have spoilt everything. They tell us our gods have no power, so our people continue to steal. (p. 176)

These changes have not abated, instead, they have gradually become entrenched in the society. According to a focus group interview on some elders in the town, sexual harassment which was barely known and condemned in the severest terms has become the order of the day (A. Uzokwe, pers commun, 24 January 2016; A. Nwanegbo, pers commun, 24 January 2016; S. Uzoka, pers commun, 24 January 2016; G. Nwedo, pers commun, 24 January 2016). On daily basis, young girls are raped and sexually molested. It was reported that in the month of August 2014, some young men invaded the only girls' secondary school in the town at night and raped most of the girls in their dormitories. In the past, though unimaginable, such acts would have led to the banishment of the people concerned from the town and a ritual cleansing of the whole town. Unfortunately, this was not the case today. Though the culprits were identified and 
prosecuted in the Court of Justice, they have since regained their freedom as if nothing happened. The story has not changed because many more people are being raped or sexually harassed that young girls and women are afraid to move freely at night unaccompanied (Records from Oguta Division ' $A$ ' Police Office). On the other hand, the town is said to be witnessing a high rate of teenage pregnancies as this is no longer considered a taboo and traditional authorities are disempowered to question anybody on such issue regarded as personal right. Other sexual issues on the rise and without any traditional mediation in the town are prostitution, abortion, divorce and abandoned babies. Sexual promiscuity has become classy and fashionable that we live in a culture of permissiveness (I. Ezeugo, pers commun, 12 March 2015).

Besides sexual immorality, the town faces the menace of armed robbers and cultists. The youths, because of their reliance on Western education, which guarantees unavailable white collar jobs, have turned to robbery and cultism in order to make ends meet. Unlike before when everybody was gainfully employed because of the opportunities the lake offered in terms of farming, fishing and trading, many youths are idle. They have failed to see the untapped opportunities in the lake because of their scorn for native life. Between 2010 and 2013, more than eight young men lost their lives in cultic fracas. During this period, the quiet town was thrown into turmoil, many people lost their properties and many others fled from their homes because of cultic hostilities among the youth (Records from Oguta Division 'A' Police Office). In the past, the mere invoking of the goddess by her ministers would not only have arrested the situation but also put heavy fines on the culprits for disturbing the peace of the town. In fact, according to the data from interviewed elders in the focused group discussion, such a calamity has never befallen the people before because it would amount to heavy penalty.

With improved social amenities and interaction, the lake has lost its religious significance as practically no religious activity goes on there. The lake has been commercialised purely as a tourist attraction. This could be likened to expunging the lake of its soul. The repercussion is what Nwapa (1966:202) noted in the natives' complain about white tourists to the lake. They complained that these foreigners, men and women, swim in the lake naked and together against the rules of the lake goddess. Not only that they are bad influence on the young ones morally, they anger the goddess and pollute the lake with their noisy engine boats. They scare away the fish and make the water unhealthy for human consumption. Worst of all by not keeping to the goddess' ordinances, the town has been witnessing one natural disaster or the other. The latest in the chains of events is the 2013 flooding that grounded the whole town. Though no life was lost, some of the natives lost their livestock, houses and farmlands to the flood (I. Ezeugo, pers commun, 12 March 2015).

An attempt was finally made to understand the opinion of the people on the critical situation the town is facing. Grouping the people according to their age bracket, we have people in the first group comprising five people who are above 70 years old. The second group of five are between the ages of 40 and 69 years, while the last group of five are between the ages 20 and 39 years. The interviewees are all natives of Oguta. They are all born, bred and resident in Oguta. Another striking common feature among them is that all of them are baptised Christians of different denominations even though not all of them are practicing Christians.

Reacting to the situation of the town, there was unanimous agreement among the people in the first group that the town and its culture have changed tremendously for the worst. The elderly relished the blissful past when there was peace and order in the whole town and nobody dared to cause problem. Unfortunately, the reverse is the case. When they were asked about the possible role Mammy Water myth played to this blissful time, they were not coherent in their response. On one hand, they all agreed that things were far better when her ordinances were observed than now but on the other hand, they all agreed that the goddess is evil. In fact, they were surprised that people are still interested in the myth, which for them is a thing in the past. This notwithstanding, they showed a strong nostalgia for the past but not for the myth.

In the second group made up of learned people, there is a total agreement that all is not well with the town. The social, religious and moral structures have collapsed without any respite in sight. When questioned about the Mammy Water myth, they all remembered the story of the capsized Nigerian army boats during the civil war in 1968. They narrated this story with little variations according to the version they heard. Even though they long for the good old days of the myth, they consider it fetish and without any power.

From the response given by members of the third group, it was lucidly observed that, they consider their town as one of the developed places in Igbo land and thus are proud of it. When reminded of the killings and sexual immoralities going on, they were fast to point out that such is happening everywhere. They acknowledged hearing the story of Mammy Water and the Nigerian army but nothing more about the myth. Obviously, for them, the myth belongs to idyllic time of the ancestors and has nothing to do with them.

\section{The way forward}

The crisis of values facing most African societies is as a result of extrapolating them from their natural milieu and filling them up with mores that are not akin to their true worldview and ethics. Knowledge without self and environmental mastering would amount to religion without faith. And this is what Africans faced with regards to Christianity and Western education. Thus, just as Yerushalmi (1982) submits that a particular and unprecedented experience of time is ours, to be reflected upon, perhaps to be channelled in new directions, so, to really move forward from this quagmire especially as it concerns the people of Oguta with regard to the disappearing Mammy Water myth, the following suggestions should be considered. They are: 
- Though the deed is already done and seemingly impossible to return to status quo, there is need to start re-telling the stories of African life. Government at all levels should mobilise all, the church, the state and families to promote people's culture. The Mammy Water myth is fast disappearing but the lake has not disappeared. Hence, the story can start from there.

- Implementing the ecological dictates of the myth has become more than before very imperative in our age of ecological disaster. We may not return to worshipping the goddess as before but may implement some of the ordinances that are ecologically proactive like not fishing in the lake on particular days so as to allow the lake to rejuvenate.

- Ethical principles and ordinances promoted by the myth should not be thrown overboard but reintroduced and encouraged in the society so as to nib the current moral laxity in the society.

- In our pluralistic world, effort should be made by all and sundry, especially governmental authorities, in the society in promoting dialogue and fraternal exchange of ideas among different religious groups. Effort should be made to discourage casting aspersions on others or engaging in hate preaching especially on traditions that promote healthy living.

- The Federal Government should introduce cultural education at all levels of education in the country. With this in place, it would be difficult for our cultural heritage, traditions, myths and legends to be lost undocumented and without reaching the future generations.

- Important historical places like the Oguta Lake with unrivalled myths and legends should be designated study centres for students of history, archaeology, anthropology, religion and culture outside of their being tourist zones.

\section{Conclusion}

Indubitably, the Mammy Water myth has been the soul of religion and culture in Oguta. It conditioned their worldview and strengthened their community life as people. Some of the issues raised by the myth that was unjustly condemned have been justified by science and events today. This is a vindication for the myth and a reason for introspection by the natives. For example, while the myth in its puritanical overture succeeded in curtailing promiscuity and violence in the town for many years without much friction, the combined efforts of Christian religion and Western education have not. In fact, the situation has worsened under the pretence of comprehensive sex education programmes in these institutions.

From the information gathered, it is obvious that the myth is disappearing or has disappeared from the land. It was blocked from reaching down to the present generation. Though the remote causes are religion and Western education, not all the natives agree to this, thus signifying a great use of propaganda and indoctrination in the process of cultural exchange. The consequence of this lacuna is that myths do not just disappear alone, they disappear with their didactics and values. Unfortunately, the major casualties are children. They will never know who they really are as was quite evident in the third group of interviewees. They will neither share from the same wisdom source like their ancestors nor know why they are the people of the lake like their ancestors. Their civilisation would be without origin, identity and heritage. It is a civilisation enshrined in overwhelming sexual promiscuity, stealing, kidnapping and killings.

The supposed development from Western education and Christianity has undermined people's collective identity, mastering and perfection. In essence, what was destroyed was not the myth but the people's creative ability. This ability was destroyed without minding that minds capable of creating myths can as well create sophisticated scientific gadgets or, at least, pave the way for their realisation in the future. By depriving the future generation this myth, their growth, both spiritually and materially, has been stunted.

Obviously, what is disappearing or being destroyed is not the myth but the people's creative ability and self-confidence. Christianity and Western education have undermined the mind that created and sustained the myth. This is because the myth fulfils in primitive culture an indispensable function: it expresses, enhances and codifies belief; it safeguards and enforces morality; and it vouches for the efficiency of ritual and contains practical rules for guidance of man (Malinowski 1954). This mind could have created or at least paved the way for authentic African civilisation without stunting the growth of the future generation morally or otherwise.

\section{Acknowledgements Competing interests}

The authors declare that they have no financial or personal relationships which may have inappropriately influenced them in writing this article.

\section{Authors' contributions}

All authors equally contributed to the research and writing of this article.

\section{References}

Achebe, C., 1958, Things fall apart, Heinemann Educational Books, Ibadan.

Achufusi, G.I., 1994, 'Female individuality and assertiveness in the novels of Ifeoma Okoye', in H. Chukwuma (ed.), Feminism in African literature, New Generation Books, Enugu.

Agorua, A.A., 2015, The Oguta Middleman: Study in socio-economic history, Arthill Publishers, Lagos.

Anyacho, E., 2005, Essential themes in the study of religion, Niger Link Printing and Publishing, Obudu.

Armstrong, K., 2009, The case for God, Alfred A. Knof, New York.

Enwo-Irem, I.N., 2013, Colonialism and education: The challenges for sustainable development in Nigeria, Mediterranean Journal of Social Sciences 4(5), 163168. https://doi.org/10.5901/mjss.2013.v4n5p163

Imam, H., 2012, Educational policy in Nigeria from the colonial era to the postindependence period, Italian Journal of Sociology of Education 1, 181204. 
Jell-Bahlsen, S., 2014, Mammy water in Igbo culture: Ogbuide of Oguta Lake, Ezu Books Ltd, Enugu.

Malinowski, B., 1954, 'Myth in primitive psychology', in R. Redfield (ed.), Magic, science and religion and other essays, p. 138, Doubleday \& Co., Inc, Garden City, NY.

Mbiti, J., 1969, African religions and philosophy, Heinemann Educational Books Ltd Nairobi.

Nwankiti, B.C., 1996, The growth and development of the Church in Nigeria, Ihem Davis Press, Ltd., Owerri.

Nwapa, F., 1966, Efuru, Heinemann Educational Books Ltd., London.
Ofili, O., 1998, A bridge across, Eternity Creation International, Lagos.

Okpewho, I., 1983, Myth in Africa: A study of its aesthetic and cultural relevance, Press Syndicate of the University of Cambridge, Cambridge.

Ugwu, C.O.T. \& Ugwueye, L.E., 2004, African traditional religion: A prolegomenon, Merit International Publishers, Lagos.

Ukeje, B.O., 1978, Education for social reconstruction, Macmillan Education Press, Hong Kong.

Yerushalmi, Y.H., 1982, Zakhor: Jewish history and Jewish Memory, University of Washington Press, Washington, DC. 